\title{
The relationship between the number of consecutive days with heat stress and milk production of Holstein dairy cows raised in a humid continental climate
}

\author{
V. Ouellet, ${ }^{1}$ V. E. Cabrera, ${ }^{2}$ L. Fadul-Pacheco, ${ }^{3}$ and É. Charbonneau ${ }^{1 *}$ \\ ${ }^{1}$ Département des Sciences Animales, Université Laval, Québec, QC, Canada G1V 0A6 \\ ${ }^{2}$ Department of Dairy Science, University of Wisconsin-Madison, Madison 53706 \\ ${ }^{3}$ Valacta, Ste-Anne-de-Bellevue, Québec, QC, Canada H9X 3R4
}

\section{ABSTRACT}

Heat stress is known to affect performance of dairy cows experiencing prolonged periods of high temperature and relative humidity. Less is known about its effects in cooler climates. The goals of the present study were to determine the prevalence of days susceptible to cause mild heat stress in dairy cows living in a humid continental climate and to investigate the relationship between the number of consecutive days of mild heat stress and milk, fat, protein, and lactose production. A 6-yr data set (2010-2015) containing 606,031 milk analysis records for 34,360 Holstein dairy cows at different parities was matched with the corresponding daily maximum temperature-humidity index. Exposure to heat stress conditions was divided into 5 categories corresponding to 0,1 to 2,3 to 4,5 to 6 , and 7 to 8 consecutive days before milk test date. On average, cows were exposed to heat stress conditions for $135.8 \pm$ $5.9 \mathrm{~d} / \mathrm{yr}$ in Southwest Quebec and $95.3 \pm 10.2 \mathrm{~d} / \mathrm{yr}$ in Eastern Quebec. Cows experiencing heat stress conditions produced on average less fat, protein, and energycorrected milk and lower fat and protein concentrations. The decrease in milk fat reached $6 \%$ for category 7 to 8 exposure of cows in parity 3 or more. The association between exposure category and milk yield and lactose yield and concentration was weak. Heat stress lowered milk fat and protein production but had little effect on milk volume output. Further research is necessary to better understand the mechanism underlying the effects of sporadic low- to medium-intensity heat stress on dairy productivity.

Key words: dairy cow, heat stress, temperaturehumidity index, productivity

Received November 27, 2018.

Accepted April 28, 2019.

*Corresponding author: edith.charbonneau@fsaa.ulaval.ca

\section{INTRODUCTION}

Dairy cows generate considerable amounts of heat associated with their basal metabolism, rumen fermentation, growth, lactation, and gestation. Heat surplus is dissipated in the environment through 4 mechanisms: conduction, convection, radiation, and evaporation. Conduction, convection, and radiation depend on the temperature gradient between the body and environment of the animal, whereas evaporation depends on the water vapor gradient at the body-air interface. Heat dissipation by dairy cows therefore becomes less effective as ambient temperature (AT) and relative humidity (RH) increase, which may cause the animal to enter into a state of heat stress.

Dairy cows respond to heat challenge by lowering their DMI and through numerous physiological mechanisms known to decrease their milk output (Bouraoui et al., 2002; Wheelock et al., 2010), reproductive performance (Schüller and Heuwieser, 2014), and health and well-being (do Amaral et al., 2011; Polsky and von Keyserlingk, 2017). Compared with other livestock, dairy cows are particularly sensitive to heat stress, making the dairy industry the livestock sector most affected by hot weather in the United States, where annual losses were estimated at $\$ 897$ million (St-Pierre et al., 2003). Moreover, as global temperatures increase over time due to climate change, so will economic losses caused by heat stress if no abatement strategies are in place (Key et al., 2014).

The temperature-humidity index (THI) is a bioclimatic metric commonly used to study heat stress in dairy cows because it has been shown to provide an accurate assessment of the level of exposure of animals confined in barns where air movement is low and solar radiation is blocked ( $\mathrm{Li}$ et al., 2009). It is calculated easily and readily because only widely available AT and $\mathrm{RH}$ data are required. A THI threshold of 72 has been found to diminish dairy cow performance (Armstrong, 1994; Ravagnolo et al., 2000). However, average milk 
production per cow has increased through genetic improvement, and it has since been shown that a THI in the range of 62 to 69 can reduce production (Zimbelman et al., 2009; Bernabucci et al., 2014; Lambertz et al., 2014).

A substantial body of work shows relationships between environmental conditions and milk characteristics. However, most studies have been conducted under conditions of prolonged acute heat stress (Wheelock et al., 2010). The effects of seasonal episodes of less severe heat stress have received much less attention. Such conditions are encountered in dairy regions characterized by cooler yearly average temperatures, warm summers, and large seasonal variations.

In view of temperature increases arising from climate change (IPCC, 2014) and recent weather anomalies, heat stress will become a global issue of growing concern in regions currently characterized by a continental climate because warm periods will increase in frequency, duration, and intensity. Establishing the actual relationship between heat stress and production performance in climates with smaller windows of high THI is important as a first step toward determining whether abatement strategies are appropriate in such climates. Moreover, it may help dairy producers to adapt to future conditions. Our objectives were (1) to determine the prevalence of days likely to cause heat stress in 2 regions of the Province of Quebec, Canada (southwestern and eastern) and (2) to investigate the relationship between the number of consecutive days of heat stress and production of milk as well as milk fat, protein, and lactose (yield and composition) by Holstein cows in these regions. Those regions were selected because of the importance of the Quebec dairy industry to the Canadian dairy sector and because they were convenient due to the availability of reliable data. We hypothesized that despite low average annual temperatures, most summer days in these regions are likely to cause heat stress in dairy cows and that an elevated number of consecutive days in this condition decreases dairy performance.

\section{MATERIALS AND METHODS}

\section{Data Set}

The dairy data used in this study were obtained from Valacta (Dairy Production Center of Expertise, Québec and Atlantic, Sainte-Anne-de-Bellevue, QC, Canada). The initial data set included 606,031 milk analysis records compiled from January 2010 to November 2015 for 34,361 Holstein cows in 279 herds located in Southwest and Eastern Quebec. Parity averaged $( \pm \mathrm{SD}) 2.7$ \pm 1.7 .
Daily production of milk, fat, protein, and lactose as well as the associated milk fat, protein, and lactose concentrations were recorded monthly. The data set also contained the DIM, lactation start date, parity number, and EBV for milk, fat, and protein yields and for percentage fat and percentage protein.

Most cows in the data set were housed in tiestall barns, which is the most common housing system in Quebec. They had no outdoor access during the year. Information on ventilation system type and heat stress abatement strategies used on the farms was not included in the data set. However, heat abatement strategies such as recirculation fans, misters, foggers, or sprinklers are unusual in Quebec tiestall dairy farms. Tiestall dairy barns in Quebec are typically mechanically ventilated, closed-sided buildings (Fournel et al., 2017). Most producers rely solely on their main ventilation system to cool the cows during summer months.

\section{Study Population}

Quebec is Canada's principal dairy-producing province. Its 354,100 dairy cows distributed in 5,546 herds (48\% of the Canadian total, with an average of 60 lactating cows per farm) accounted for $47 \%$ of Canadian milk production during the years 2010 to 2015 , with an average $( \pm \mathrm{SD})$ of $9,064 \pm 101 \mathrm{~kg} /$ cow per lactation (CDIC, 2017).

According to Köppen's (1918) classification, the climate of the southwest and eastern regions of Quebec is characterized as humid continental. The main features of such a climate are temperatures averaging below $-3^{\circ} \mathrm{C}$ for at least $1 \mathrm{mo}$ of the year and above $10^{\circ} \mathrm{C}$ for at least 4 mo of the year. This climate also occurs in most of Northern and Northeast China, Eastern and Southeast Europe, in the Central and Upper Eastern United States, and in Central and Southeast Canada.

Holstein dairy cattle in Southwest and Eastern Quebec are an interesting case study because they represent a large population selected intensively for superior milk components yields. Moreover, cows raised in these regions experience annual temperature variations ranging from $-33.8^{\circ} \mathrm{C}$ during winter months to $36.5^{\circ} \mathrm{C}$ during summer months (recorded at meteorological stations). As temperatures increase due to climate change, dairy cows living in these regions will likely experience more days likely to cause heat stress of higher intensity in the near future (IPCC, 2014).

\section{Data Editing}

Test-day (TD) records with missing values (milk, fat, protein, lactose, genetic values, or weather data) were removed from the data set. Days in milk were divided 
into classes defined as 1 class for every $30 \mathrm{~d}$, resulting in 12 classes. Calving year and month were added to the data set. The cows were also categorized on the basis of parity: first, second, third, and beyond third lactations.

After editing, the data set included 452,147 TD records for 32,444 Holstein dairy cows at parity $2.5 \pm 1.6$ (mean \pm SD) from 279 dairy herds. Of these, 149,119 $(33 \%)$ were in first parity, $117,233(26 \%)$ were in second parity, and 185,795 (41\%) were in third parity or beyond. First-parity cows produced on average $( \pm \mathrm{SD})$ $26.8 \pm 6.6 \mathrm{~kg}$ of milk/d with $4.1 \pm 0.2 \%$ fat and 3.3 $\pm 0.4 \%$ protein. Second-parity cows produced $30.7 \pm$ $6.6 \mathrm{~kg}$ of milk/d with $4.0 \pm 0.8 \%$ fat and $3.4 \pm 0.4 \%$ protein. Production at third parity or more was $32.2 \pm$ $10.2 \mathrm{~kg}$ of milk/d with $4.0 \pm 0.8 \%$ fat and $3.3 \pm 0.4 \%$ protein.

\section{ECM Calculation}

Energy-corrected milk containing $3.14 \mathrm{MJ} / \mathrm{kg}$ was calculated and added to the data set from the determined yields of protein, fat, and lactose (Madsen et al., 2008):

$$
\begin{gathered}
\text { ECM }(\mathrm{kg} / \mathrm{d})=23.8 \times(\text { protein yield, } \mathrm{kg} / \mathrm{d}) \\
+38.9 \times(\text { fat yield }, \mathrm{kg} / \mathrm{d})+16.3 \\
\times(\text { lactose yield }, \mathrm{kg} / \mathrm{d}) / 3.14
\end{gathered}
$$

\section{Environmental Data}

Hourly AT and RH were retrieved for the years 2010 to 2015 from 8 meteorological stations (3 from Southwest Quebec, 5 from Eastern Quebec) chosen on the basis of their distance from the barns in the data set and the availability of $\mathrm{RH}$ data. Hourly readings were then expressed per calendar day by retrieving maximum AT $\left({ }^{\circ} \mathrm{C}\right)$ and its corresponding $\mathrm{RH}(\%)$ value, which corresponded to daily minimum $\mathrm{RH}$. To characterize the weather conditions prevailing during our study, daily maximum $\mathrm{AT}\left({ }^{\circ} \mathrm{C}\right)$ and minimum $\mathrm{RH}(\%)$ were averaged on an annual basis and on a seasonal basis $($ fall $=$ September, October, November; winter $=$ December, January, February; spring = March, April, May; summer = June, July, August) using the MEAN procedure of SAS (version 9.4; SAS Institute Inc., Cary, $\mathrm{NC})$.

\section{THI Calculations}

Retrieved weather data were then used to calculate

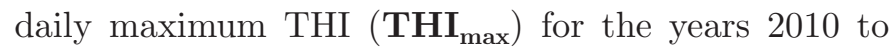

2015 using the equation reported by Kendall et al. (2008):

$$
\begin{aligned}
T H I_{\max } & =\left(1.8 \times A T_{\max }+32\right)-[(0.55-0.0055 \\
& \left.\left.\times R H_{\min }\right) \times\left(1.8 \times A T_{\max }-26\right)\right],
\end{aligned}
$$

where $A T_{\max }$ is the daily maximum AT $\left({ }^{\circ} \mathrm{C}\right)$ and $R H_{\text {min }}$ is the daily minimum $\mathrm{RH}(\%)$. This equation was chosen because it has been used previously in animal trials conducted in a continental climate (Schüller and Heuwieser, 2014; Shock et al., 2016). The daily maximum THI was chosen instead of the average THI because it fits public weather station data better (Ravagnolo and Misztal, 2002) and because milk yield on a given day is more sensitive to maximum THI extremes than to daily average THI (Brügemann et al., 2012).

The $\mathrm{THI}_{\max }$ from the closest meteorological station were then merged to the corresponding TD in the data set. This step was repeated for the $12 \mathrm{~d}$ before TD. A range of $12 \mathrm{~d}$ was an initial arbitrary choice based on the results of a study conducted by Bernabucci et al. (2014), who reported that this period is sufficiently long to estimate the length in which the productive traits are significantly affected by THI.

\section{Calculation of Consecutive Days with Heat Stress}

It has been shown that THI has a persistent effect on all milk traits (Bernabucci et al., 2014); therefore, the relationship between weather conditions recorded on TD and on the $12 \mathrm{~d}$ prior and milk performance (yield and composition) was investigated by performing linear regressions with the REG procedure of SAS version 9.4. For this purpose, milk, fat, protein, and lactose production and milk composition (fat, protein, and lactose concentrations) were used sequentially as the outcome of interest, and the $\mathrm{THI}_{\max }$ of each of the $12 \mathrm{~d}$ before milk analysis were used sequentially as the explanatory variable. Only days with a significant effect $(P<0.05)$ were included in the number of consecutive days with heat stress calculations.

The number of consecutive days with heat stress was defined as the sum of the successive days with $\mathrm{THI}_{\max }$ $\geq 65$ during the $8 \mathrm{~d}$ up to the milk analysis day. The numbers of consecutive day with heat stress were then grouped into 5 categories irrespective of their relative distance to TD: $0=$ no days with heat stress, 1 to $2=$ 1 or $2 \mathrm{~d}, 3$ to $4=3$ or $4 \mathrm{~d}, 5$ to $6=5$ or $6 \mathrm{~d}$, and 7 to $8=7$ or $8 \mathrm{~d}$. The distribution of each category was calculated using the UNIVARIATE and FREQ procedures of SAS (version 9.4). 


\section{Heat Stress Analysis Model}

The relationship between the number of consecutive days with heat stress (category) and milk traits on the milk analysis day was investigated using the HPMIXED procedure of SAS (version 9.4). All variables and possible interactions between variables were included in the initial model. Manual backward selection was performed and variables with $P$-values $<0.05$ were retained for inclusion in the final model. Variables were assessed for colinearity using Pearson and Spearman rank-order correlations. Continuous variables were assessed for linearity by including a quadratic term in the model. When the quadratic term was significant, it was included in the model; otherwise, the variable was modeled as linear.

The test of significance of the random effects involved fitting the model and then alternatively dropping each effect and comparing Bayesian information criterion test statistics. The final model used to describe the relationship between measured milk yield and fat, protein, and lactose yield and concentration and the number of consecutive days of heat stress was as follows:

$$
\begin{gathered}
\mathrm{Y}_{\mathrm{ijklmno}}=\mathrm{DIM}_{\mathrm{i}}+\text { DwithHS }_{\mathrm{j}}+\text { Lact }_{\mathrm{k}}+\mathrm{GNTIC}_{\mathrm{l}} \\
+ \text { DwithHS }_{\mathrm{j}} \times \text { Lact }_{\mathrm{k}}+\mathrm{DIM}_{\mathrm{i}} \times \text { Lact }_{\mathrm{k}}+\operatorname{Anm}(\mathrm{Hrd})_{\mathrm{m}} \\
+\operatorname{Hrd}(\mathrm{cy})_{\mathrm{n}}+\operatorname{Anm}(\operatorname{Hrd} \times \operatorname{Lact} \times \mathrm{cy} \times \mathrm{cm})_{\mathrm{o}}+\mathrm{E}_{\mathrm{ijklmno}},
\end{gathered}
$$

where $Y_{i j k l m n o}$ is a measurement of milk yield and milk fat, protein, and lactose yields and concentrations; $D I M_{i}$ is the fixed effect of the DIM category; DwithHS is the fixed effect of the consecutive days of heat stress category; Lact $t_{k}$ is the fixed effect of the parity category; $G N T I C_{l}$ is the fixed effect of the estimated breeding value for milk, fat, and protein yields or fat and protein concentrations; DwithHS $S_{j} \times$ Lact $_{k}$ and DIM $_{i} \times$ Lact $_{k}$ are fixed-effect interactions; $A n m(H r d)_{m}$ is the random animal effect nested within the herd; $\operatorname{Hrd}(c y)_{n}$ is the random herd effect nested within the calving; $\mathrm{Anm}(\mathrm{Hrd}$ $\times$ Lact $\times c y \times c m)_{o}$ is the random animal effect nested within the interaction between the herd, lactation, calving year, and calving month; and $E_{i j k l m n o}$ is the random residual effect.

Residuals were tested for normality. Least squares means were estimated for the number of consecutive days of heat stress, and differences were tested using the GLIMMIX procedure of SAS version 9.4. Differences were considered significant at $P<0.05$.

\section{RESULTS AND DISCUSSION}

\section{Environmental Data}

Heat stress is a condition usually associated with regions characterized by tropical or arid climates. Information on its prevalence in regions of continental climate is scant. According to Köppen's (1918) classification, the climate of Southwest Quebec and Eastern Quebec is humid continental. Weather-induced heat stress in dairy cows is less common and less intense in such regions than in tropical and arid climates. Its effect may be less serious than reported in hotter climates.

In the present study, mean daily $\mathrm{AT}_{\max }$ and $\mathrm{RH}_{\min }$ recorded at local weather stations during the months of June, July, and August for 2010 to 2015 were 25.5 $\pm 3.7^{\circ} \mathrm{C}$ and $70.1 \pm 10.3 \%$, respectively, in Southwest Quebec and $21.9 \pm 4.3^{\circ} \mathrm{C}$ and $74.9 \pm 12.2 \%$, respectively, for Eastern Quebec (Table 1). Furthermore, both regions were characterized by large seasonal weather variations because these values during the months of December, January, and February were $-2.9 \pm 6.4^{\circ} \mathrm{C}$ and $76.9 \pm 10.3 \%$, respectively, in Southwest Quebec and $-4.8 \pm 6.5^{\circ} \mathrm{C}$ and $75.8 \pm 12.0 \%$, respectively, in Eastern Quebec (Table 1).

\section{THI Calculations}

The THI is used frequently to gauge heat stress levels in dairy cows because it combines the effects of

\begin{tabular}{|c|c|c|c|c|c|c|c|c|}
\hline Item & \multicolumn{4}{|c|}{ Southwest Quebec } & \multicolumn{4}{|c|}{ Eastern Quebec } \\
\hline $\begin{array}{l}\mathrm{AT}_{\max }{ }^{2}\left({ }^{\circ} \mathrm{C}\right) \\
\mathrm{RH}_{\min }{ }_{3}(\%) \\
\mathrm{THI}_{\max }\end{array}$ & $\begin{array}{l}14.1 \pm 7.9 \\
74.2 \pm 10.3 \\
57.4 \pm 5.5\end{array}$ & $\begin{aligned}-2.9 & \pm 6.4 \\
76.9 & \pm 11.1 \\
31.0 & \pm 9.3\end{aligned}$ & $\begin{array}{l}11.8 \pm 9.3 \\
58.8 \pm 15.3 \\
54.0 \pm 13.4\end{array}$ & $\begin{array}{l}25.5 \pm 3.7 \\
70.1 \pm 10.3 \\
74.5 \pm 5.5\end{array}$ & $\begin{array}{l}10.8 \pm 7.4 \\
75.8 \pm 12.0 \\
52.3 \pm 11.3\end{array}$ & $\begin{aligned}-4.8 & \pm 6.5 \\
76.0 & \pm 10.6 \\
28.2 & \pm 9.1\end{aligned}$ & $\begin{array}{c}7.1 \pm 8.3 \\
71.3 \pm 14.6 \\
46.8 \pm 12.2\end{array}$ & $\begin{array}{l}21.8 \pm 4.2 \\
74.9 \pm 12.2 \\
69.2 \pm 6.2\end{array}$ \\
\hline
\end{tabular}

Table 1. Average maximum ambient temperature $\left(\mathrm{AT}_{\max }\right)$, minimum relative humidity $\left(\mathrm{RH}_{\min }\right)$, and maximum temperature-humidity index $\left(\mathrm{THI}_{\max }\right)$ by season $^{1}$ in Southwest Quebec and Eastern Quebec during the period 2010 to 2015

${ }^{1}$ Fall = September, October, and November; winter = December, January, and February; spring = March, April, and May; summer = June, July, and August.

${ }^{2}$ Calculated from weather station data.

${ }^{3} \mathrm{THI}=(1.8 \times \mathrm{AT}+32)-[(0.55-0.0055 \times \mathrm{RH}) \times(1.8 \times \mathrm{AT}-26)]$. 
temperature and humidity. It has been shown repeatedly that cow milk and milk component yields start to decrease when THI exceeds a specific threshold (Zimbelman et al., 2009; Bernabucci et al., 2014), which may vary depending on the region, the THI formula, and cow productivity because higher milk output leads to higher sensitivity to thermal stress. In the present study, a threshold of 65 was chosen as the THI at which milk production and components started to decline, as has been suggested in previous studies conducted under comparable environmental conditions with cows of similar productivity (Brügemann et al., 2012; Lambertz et al., 2014).

In the present study, THI data obtained from local meteorological stations were presumed to represent on-farm environmental conditions. One conclusion of a study of the suitability of using meteorological data from the nearest weather station as proxies for conditions inside barns at 48 Ontario dairy farms was that daily THI inside barns tended to be 1 unit higher than that measured at the nearest weather station (Shock et al., 2016). Consistently higher THI in barns than in weather data from nearby stations had been observed earlier (Schüller et al., 2013). The consequences of such underestimations need to be considered. To obtain values more representative of actual conditions inside barns, we used $\mathrm{AT}_{\max }$ and $\mathrm{RH}_{\min }$ instead of average $\mathrm{AT}$ and $\mathrm{RH}$ and we calculated the daily $\mathrm{THI}_{\max }$ to which cows were exposed during the day. The THI maximum as defined here is more realistic than the average THI because high temperatures are always associated with lower humidity (De Rensis et al., 2015). This is also consistent with other studies showing that $\mathrm{THI}_{\max }$ is a more reliable indicator of conditions likely to cause heat stress in dairy cows (Ravagnolo et al., 2000; Bernabucci et al., 2014; De Rensis et al., 2015).

Average daily $\mathrm{THI}_{\max }$ calculated during the months of June, July, and August were $74.5 \pm 5.5$ in Southwest Quebec and 69.2 \pm 6.2 in Eastern Quebec (Table 1). The cows in the present study were therefore exposed to conditions likely to cause heat stress. It has been observed that THI in this range may induce mild discomfort in dairy cows (De Rensis et al., 2015). In Southwest Quebec, the average number of days per year during which $\mathrm{THI}_{\max }$ reaches or exceeds 65 is $135.8 \pm 5.9$. In Eastern Quebec, this number is $95.3 \pm 10.2$. Dairy cows in these 2 regions therefore may be prone to heat stress during 37 and $26 \%$ of the year, respectively. However, the number of days with heat stress conditions may vary between herds as ventilation systems in tiestall barns can vary considerably in their ability to move air and thus to contribute to effective heat abatement in dairy cows. This also applies to heat stress abatement strategies such as recirculation fans, misters, and sprinklers systems. Considering the absence of information on ventilation system and heat stress abatement strategies in our data set, this could not be addressed in our study.

\section{Consecutive Days with Heat Stress Before Milk Analysis Day}

The $\mathrm{THI}_{\max }$ recorded on the milk analysis day was not associated $(P>0.05)$ with the test results (Table 2 ). We therefore excluded it from our calculations. The effects of AT on milk production parameters have been found to peak during the 24 to $48 \mathrm{~h}$ following the stress (Collier et al., 1981), and the effects of THI on milk yield may be measured 2 d later (West et al., 2003). This explains why conditions recorded on the analysis day appeared not to affect the associated milk production. In addition, when the analysis was performed on a morning milking, the recorded $\mathrm{THI}_{\max }$ was not applicable because the maximum for the day was not yet reached.

Overall, $8 \mathrm{~d}$ before TD were included in the number of consecutive days with $\mathrm{HS}\left(\mathrm{THI}_{\max } \geq 65\right)$ calculations (Table 2). The use of weather data going back $8 \mathrm{~d}$ before milk analysis to calculate the number of consecutive days with heat stress $\left(\mathrm{THI}_{\max } \geq 65\right)$ is consistent with a previous study showing that milk yield was negatively affected by the THI during this period (Bernabucci et al., 2014). However, Bernabucci et al. (2014) also reported that the effect was found to persist for up to $12 \mathrm{~d}$ for milk components yield. This was not confirmed in our study.

Overall, $55.7 \%$ of the milk analysis records in the years 2010 to 2015 fell in category 0 (no days with heat stress), whereas the remaining $44.3 \%$ were in category 1 to 2 or higher (at least $1 \mathrm{~d}$ likely to cause heat stress). More specifically, $15.2 \%$ were classified as being in category 1 to $2,14.1 \%$ in category 3 to $4,2.5 \%$ in category 5 to 6 , and $12.5 \%$ in category 7 to 8 .

\section{Effects on Milk, Fat, Protein, Lactose, and ECM Yields}

Under heat stress conditions, dairy cows exhibit multiple behavioral and physiological responses that may have deleterious effects on milk and milk component production. Information on the relationship between environmental conditions and milk productivity in humid continental climates is currently limited, which makes it unclear what abatement actions should be taken on farms. The relationships between the number of consecutive days of heat stress and milk, fat, protein, and lactose yields are shown in Table 3 . 


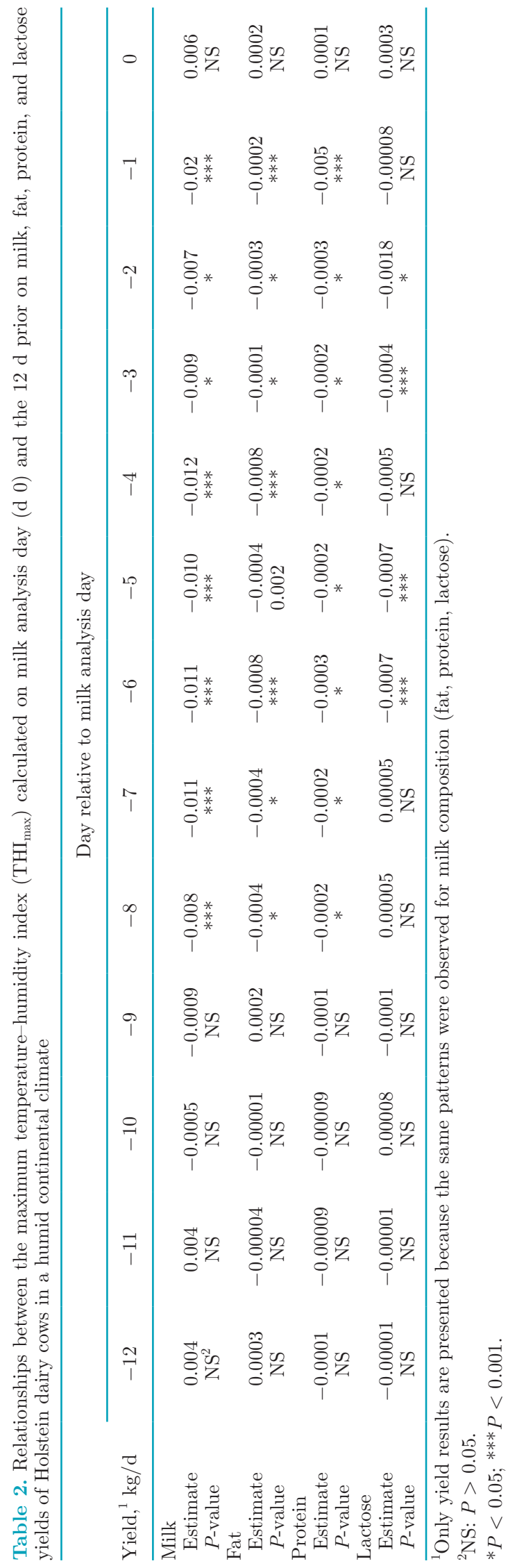

Journal of Dairy Science Vol. 102 No. 9, 2019

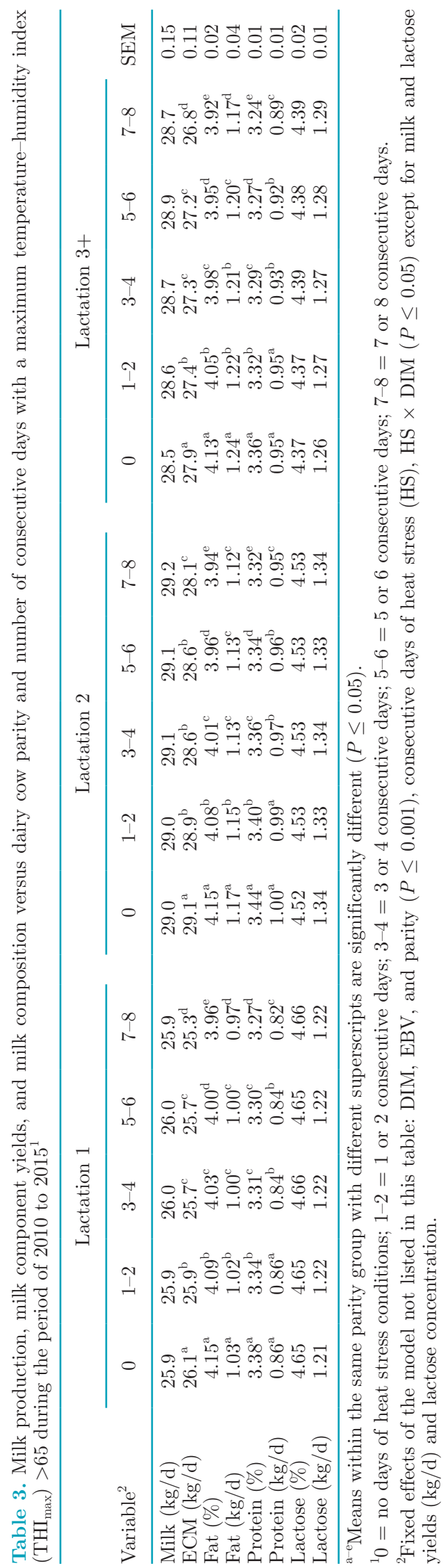


The lack of significant difference for milk production between no heat stress category and stress increasing numbers of consecutive days categories was unexpected. Significant decreases in milk yield from cows in the latter situation have been reported repeatedly in animal trials (Kadzere et al., 2002; West et al., 2003; Wheelock et al., 2010). Moreover, Bernabucci et al. (2014), who also fitted a linear model based on a large data set of Italian Holstein dairy cows' milk test records, also observed a significant negative relationship between high THI values and milk traits. This was not confirmed in our study and is probably due in part to higher temperatures; the authors indicated that the daily THI at which milk production started to decline ranged from 71 to 76 depending on parity. We suggest that when under more intense repeated heat stress episodes, the cows reduced their DMI further and the direct heat stress effects on the mammary gland were stronger, hence the larger decreases in milk yield observed in the Bernabucci et al. (2014). Moreover, the overall heat load on cows kept inside throughout the year (the case in our study) is probably lower, although we cannot validate this using our data set.

Significant decreases in milk fat yield under heat stress conditions have been reported in several studies over the years (Bouraoui et al., 2002; Hammami et al., 2013; Bernabucci et al., 2014). However, other studies suggest no effect (Knapp and Grummer, 1991; Wheelock et al., 2010). In our study, cows experiencing $1 \mathrm{~d}$ or consecutive days of heat stress produced less fat on the analysis day compared with cows not heat stressed (Table 3). For all parities, declines of $0.02 \mathrm{~kg} / \mathrm{d}$ were observed when cows were heat stressed for $1 \mathrm{~d}$ or 2 consecutive days. This is in the range reported in the Italian Holstein study $(-0.02$ to $-0.07 \mathrm{~kg} / \mathrm{d}$; Bernabucci et al., 2014). In the present study, the decrease reached a maximum of $-0.06 \mathrm{~kg}(6 \%)$ when comparing cows that were heat stressed for 7 or 8 consecutive days with unstressed cows in third parity or beyond.

Considering the absence of association between milk yield and heat stress, our results suggest that fat yield is more sensitive than milk yield to an increased number of days of heat stress. This is consistent with the effects of THI on Italian Holsteins (Bernabucci et al., 2014). We hypothesize that this sensitivity is related to current genetic selection programs in Canada. Payment of dairy producers on the basis of the component content of raw milk has motivated the selection of animals capable of superior milk fat and protein yields. This particular superior performance may be more sensitive to heat stress. One conclusion of a study of the effects of heat stress on yield traits is that fat yield, of C18:1 cis-9 UFA in particular, was the most sensitive to hot days in a temperate climate (Hammami et al., 2015), which is consistent with our findings in a humid continental climate. Moreover, considering the relationship between water intake and milk yield (Steiger Burgos et al., 2001), providing adequate levels of water may help dairy cows maintain their milk production under heat stress conditions. However, this could not be validated in the current study.

In addition to decreased milk fat yield, hot environments are reportedly related to decreases in milk protein yield (Bernabucci et al., 2014; Cowley et al., 2015). This decline has been associated with a series of changes in physiology, nutrient metabolism, and nutrient partitioning to the mammary gland under heat stress (Cowley et al., 2015). Heat stress may also increase systemic AA utilization, thus limiting the supply to the mammary gland for milk protein synthesis (Gao et al., 2017). Our results are consistent with the findings of previous animal trials (Cowley et al., 2015; Gao et al., 2017) because dairy cows subjected to an increased number of consecutive days of heat stress produced less protein on the milk analysis day $(P<0.05)$ compared with unstressed cows. However, our results showed that cows of all parities had to be stressed for at least 3 consecutive days to respond with a significant decrease in protein yield. The THI threshold beyond which heat stress starts to impair dairy productivity may explain this in part. A weighted THI breakpoint of 72 has been reported for protein yield (Bernabucci et al., 2014). However, we chose a threshold of 65 , which may be too low to observe effects on milk protein synthesis after 1 or 2 consecutive days of heat stress. For cows at their first, second, and third parity or more, decreases of $0.04,0.05$, and $0.06 \mathrm{~kg}$, respectively, were observed after 7 or 8 consecutive days of heat stress compared with conditions of no stress.

For all parities, heat stress was not associated $(P$ $>0.05$ ) with lactose yield (Table 3 ). This result does not support previous findings that heat stress is associated with lactose production decreases of 200 to $400 \mathrm{~g} / \mathrm{d}$ (Rhoads et al., 2009; Wheelock et al., 2010). Such decreases apparently depend on reduction of feed intake (Rhoads et al., 2009), and exposure to THI ranging from 73 to 82 for 9 consecutive days (well above the stresses involved in our study) might also be a factor (Rhoads et al., 2009; Wheelock et al., 2010). We speculate that the decreases in DMI were smaller in our study because the THI was lower. However, we cannot validate this because DMI data were not included in our data set. Another possibility may be related to insulin, as Wheelock et al. (2010) reported a marked increase in blood insulin levels under heat stress. Because heat stress was less intense in our study, blood 
insulin levels were probably lower in study cows than in cows exposed to moderate to severe heat stress, allowing study cows to utilize exogenous carbohydrate at a slower rate. This could have affected lactose yield because lactose secretion is generally proportional to glucose availability (Kronfeld, 1982).

In our study, ECM yield was higher among cows that were not heat stressed in all parity groups compared with cows stressed for at least $1 \mathrm{~d}$. The greatest difference was observed between category 0 and category 7 to 8. Energy-corrected milk losses between these categories were $0.8,1.0$, and $1.1 \mathrm{~kg}$ for cows in first, second, and third or greater parities, respectively. The differences between the heat stress categories were not surprising considering the effects found in milk components in our study.

\section{Effects on Milk Composition}

In the present study, the relationships between the number of consecutive heat stress days and milk component yields were also observed for milk composition (fat, protein, and lactose concentrations) because milk production was unchanged (Table 3). In other words, nonstressful condition was associated with milk being significantly fatter and richer in protein compared with milk produced under heat stress conditions. Moreover, as little as 1 heat stress day was associated with a decline in milk fat and protein. As observed for fat and protein yields, the maximum difference in milk fat and protein concentrations was observed between categories 0 and 7 to 8 .

\section{CONCLUSIONS}

This study is the first to explore the relationship between the accumulation of consecutive days of heat stress conditions and milk production by dairy cows in a humid continental climate. We demonstrated that cows exposed to an increased number of consecutive days with heat stress produced less fat, protein, and ECM on TD and had a lower milk fat and protein composition than cows not exposed to heat stress, whereas milk production and lactose were unchanged. Our results thus suggest that milk components are more sensitive than milk yield to heat stress experienced by Holstein cows in a humid continental climate. This is of importance for Canadian dairy farmers, considering that they are paid on the basis of raw milk composition (butterfat, protein, and other solids). More attention should be paid to heat stress experienced by dairy cows to lessen the effect of the current humid continental climate as well as future climatic conditions on dairy productivity.

\section{ACKNOWLEDGMENTS}

Financial support for this study was received in the form of grants from the Consortium on Regional Climatology and Adaptation to climate change Ouranos (Montreal, QC, Canada) and the Québec government Fonds vert/PACC 2013-2020 initiative. The Natural Sciences and Engineering Research Council of Canada (Quebec, Canada) and Op+lait (Quebec, Canada) also contributed through a scholarship.

\section{REFERENCES}

Armstrong, D. V. 1994. Heat stress interaction with shade and cooling. J. Dairy Sci. 77:2044-2050.

Bernabucci, U., S. Biffani, L. Buggiotti, A. Vitali, N. Lacetera, and A. Nardone. 2014. The effects of heat stress in Italian Holstein dairy cattle. J. Dairy Sci. 97:471-486.

Bouraoui, R., M. Lahmar, A. Madjoub, M. Djemali, and R. Belyea. 2002. The relationship between temperature-humidity index with milk production of dairy cows in Mediterranean climate. Anim. Res. 51:479-491.

Brügemann, K., E. Gernand, U. König von Borstel, and S. König. 2012. Defining and evaluating heat stress thresholds in different dairy cow production systems. Arch. Tierzucht 55:13-24.

Canadian Dairy Information Centre. 2017. Dairy facts and figures. Accessed Feb. 12, 2018. http://www.dairyinfo.gc.ca/index_e.php ?s1=dff-fcil/.

Collier, R. J., R. M. Eley, A. K. Sharma, R. M. Pereira, and D. E. Buffington. 1981. Shade management in subtropical environment for milk yield and composition in Holstein and Jersey cows. J. Dairy Sci. 64:844-849.

Cowley, F. C., D. G. Barber, A. V. Houlihan, and D. P. Poppi. 2015. Immediate and residual effects of heat stress and restricted intake on milk protein and casein composition and energy metabolism. J. Dairy Sci. 98:2356-2368.

De Rensis, F., I. Garcia-Ispierto, and F. Lopez-Gatis. 2015. Seasonal heat stress: Clinical implications and hormone treatments for the fertility of dairy cows. Theriogenology 84:659-666.

do Amaral, B. C., E. E. Connor, S. Tao, M. J. Hayen, J. W. Bubolz, and G. E. Dahl. 2011. Heat stress abatement during the dry period influences metabolic gene expression and improves immune status in the transition period of dairy cows. J. Dairy Sci. 94:86-96.

Fournel, S., V. Ouellet, and E. Charbonneau. 2017. Practices for alleviating heat stress of dairy cows in humid continental climates: A literature review. Animals (Basel) 7:37.

Gao, S. T., J. Guo, S. Y. Quan, X. M. Nan, M. V. Sanz Fernandez, L. H. Baumgard, and D. P. Bu. 2017. The effects of heat stress on protein metabolism in lactating dairy cows. J. Dairy Sci. 100:5040-5049.

Hammami, H., J. Bormann, N. M'hamdi, H. Montaldo, and N. Gendler. 2013. Evaluation of heat stress effects on production traits and somatic cell scores of Holsteins in a temperate environment. J. Dairy Sci. 96:1844-1855.

Hammami, H., J. Vandenplas, M.-L. Vanrobays, B. Rekik, C. Bastin and N. Gendler. 2015. Evaluation of heat stress effects on yield traits, udder health, and fatty acids of Walloon Holstein cows. J. Dairy Sci. 98:4956-4968.

IPCC (Intergovernmental Panel on Climate Change). 2014. Climate change 2014: Synthesis report. Accessed Apr. 10, 2015. https:// www.ipcc.ch/report/ar5/.

Kadzere, C. T., M. R. Murphy, N. Silanikove, and E. Maltz. 2002. Heat stress in lactating dairy cows: A review. Livest. Prod. Sci. 77:59-91.

Kendall, P. E., C. B. Tucker, D. E. Dalley, D. A. Clarck, and J. R. Webster. 2008. Milking frequency affects the circadian body temperature rhythm in dairy cows. Livest. Sci. 117:130-138. 
Key, N., S. Sneeringer, and D. Marquardt. 2014. Climate change, heat stress, and U.S. dairy production. Economic Research Report No. 175. USDA Economic Research Service, Washington, DC.

Knapp, D. M., and R. R. Grummer. 1991. Response of lactating dairy cows to fat supplementation during heat stress. J. Dairy Sci. 74:2573-2579.

Köppen, W. 1918. Klassifikation der Klimate nach temperatur, niederschlagund jahreslauf. Petermanns Geogr. Mitt. 64:193-203.

Kronfeld, D. S. 1982. Major metabolic determinants of milk volume, mammary efficiency, and spontaneous ketosis in dairy cows. J. Dairy Sci. 65:2204-2212.

Lambertz, C., C. Sanker, and M. Gauly. 2014. Climatic effects on milk production traits and somatic cell score in lactating Holstein-Friesian cows in different housing systems. J. Dairy Sci. 97:319-329.

Li, S., K. G. Gebremedhin, C. N. Lee, and R. J. Collier. 2009. Evaluation of thermal stress indices for cattle. Pages 2283-2302 in Proc. 2009 ASABE Annual Meeting. ASABE, St. Joseph, MI.

Madsen, T. G., M. O. Nielsen, J. B. Andersen, and K. L. Ingvartsen. 2008. Continuous lactation in dairy cows: Effect on milk production and mammary nutrient supply and extraction. J. Dairy Sci. 91:1791-1801.

Polsky, L., and M. A. G. von Keyserlingk. 2017. Invited review: Effects of heat stress on dairy cattle welfare. J. Dairy Sci. 100:8645-8657.

Ravagnolo, O., I. Misztal, and G. Hoogenboom. 2000. Genetic component of heat stress in dairy cattle, development of heat index function. J. Dairy Sci. 83:2120-2125.

Ravagnolo, O., and I. Misztal. 2002. Effect of heat stress on nonreturn rate in Holstein cows: Genetic analysis. J. Dairy Sci. 85:3092-3100.

Rhoads, M. L., R. P. Rhoads, M. J. VanBaale, R. J. Collier, S. R Sanders, W. J. Weber, B. A. Crooker, and L. H. Baumgard. 2009 Effects of heat stress and plane of nutrition on lactating Holstein cows: I. Production, metabolism and aspects of circulating somatotropin. J. Dairy Sci. 92:1986-1997.
Schüller, L. K., O. Burfeind, and W. Heuwieser. 2013. Short communication: Comparison of ambient temperature, relative humidity, and temperature-humidity index between on-farm measurements and official meteorological data. J. Dairy Sci. 96:7731-7738.

Schüller, L. K., and W. Heuwieser. 2014. Impacts of heat stress on conception rate of dairy cows in the moderate climate considering different temperature-humidity index thresholds, periods relative to breeding, and heat load indices. Theriogenology 81:1050-1057.

Shock, D. A., S. J. Leblanc, K. E. Leslie, K. Hand, M. A. Godkin, J. B. Coe, and D. F. Kelton. 2016. Studying the relationship between on-farm environmental conditions and local meteorological station data during summer. J. Dairy Sci. 99:2169-2179.

Steiger Burgos, M., M. Senn, F. Sutter, M. Kreuzer, and W. Langhans. 2001. Effect of water restriction on feeding and metabolism in dairy cows. Am. J. Physiol. Regul. Integr. Comp. Physiol. 280:R418-R427.

St-Pierre, N. R., B. Cobanov, and G. Schnitkey. 2003. Economic losses from heat stress by US livestock industries. J. Dairy Sci. 86 (E Suppl.):E52-E77.

West, J. W., B. G. Mullinix, and J. K. Bernard. 2003. Effects of hot, humid weather on milk temperature, dry matter intake, and milk yield of lactating dairy cows. J. Dairy Sci. 86:232-242.

Wheelock, J. B., R. P. Rhoads, M. J. VanBaale, S. R. Sanders, and L. H. Baumgard. 2010. Effects of heat stress on energetic metabolism in lactating Holstein cows. J. Dairy Sci. 93:644-655.

Zimbelman, R. B., R. P. Rhoads, M. L. Rhoads, G. C. Duff, L. H. Baumguard, and R. J. Collier. 2009. A re-evaluation of the impact of temperature humidity index (THI) and black globe humidity index (BGHI) on milk production in high producing dairy cows. Pages 158-169 in 24th Annu. Southwest Nutrition Management Conf., Tempe, AZ. University of Arizona, Tucson. 